\title{
A Contribution to Critique of 'Global Crisis Situation': Critical Dialogue Between Cultural-Historical Activity Theory and Iranian Marxist Tradition
}

\author{
Sohrab Rezvani ${ }^{1}$ (D)
}

Received: 21 July 2020 / Revised: 20 January 2021 / Accepted: 23 January 2021 /

Published online: 8 February 2021

(c) The Author(s), under exclusive licence to Springer Nature Switzerland AG part of Springer Nature 2021

\begin{abstract}
In this article, based on mutual appropriation of concepts from cultural-historical activity theory (especially Andy Blunden's works) and Iranian Marxist tradition (especially Kamal Khosravi's ideas), I have elaborated two crises which, we believe, are main characteristics of our historical stage and other crises are manifestations of them: (a) crisis of historical perspective on human self-emancipation and (b) crisis of theory in emancipatory social science. Crisis of historical perspective indicates lack of integrated worldview and concept about emancipated future, while crisis of theory addresses the fundamental problem of theoretical categories in expressing relations between elements and factors of reality. Categories of mode of existence (Marx, Khosravi) and mode of collaboration (Blunden) are proposed in order to solve these crises. Based on the mutual appropriation of mode of existence and mode of collaboration, I have tried to formulate three modes of existence of projects (class-project, project, and life-project) which can explain the totality of a social reality. These crises and proposed categories have been elaborated in this article, in critical dialogue with some theoretical frameworks like feminist account of intersectionality and German-Scandinavian Critical Psychology's main concept: conduct of everyday life.
\end{abstract}

Keywords Emancipatory science $\cdot$ Marx $\cdot$ Cultural-historical activity theory · Intersectionality $\cdot$ Critical psychology $\cdot$ Everyday life

"To be radical is to go to the root of the matter. For man, however, the root is man himself." Karl Marx

It appears that there are lots of various types of crises that we can talk about. I am sure that many scholars, here, have talked about many of the crises, from grand crisis of climate change to more small and specific crises in everyday life of those who have lost their jobs or those who are struggling with COVID-19. But, I am going to raise our attention to another set of crises which, we believe, resolving them is even more necessary and primary than giant crises we are dealing with: crisis of historical perspective on

Sohrab Rezvani

Sohrab.rezvani@hotmail.com

1 Tehran, Iran 
human self-emancipation and crisis of theory (Khosravi, 2017). Based on Khosravi's argument, we believe all different types of crises in the course of our global everyday life are different manifestations of these two crises. In this article, I am going to explain these interrelated crises in our contemporary history and propose some methodological and theoretical suggestions, specifically introducing categories of mode of existence (Marx, 1867; Khosravi, 2020a) and mode of collaboration (Blunden, 2010, 2014), in order to solve these crises. I am doing this investigation as practice of mutual appropriating culturalhistorical activity theory (especially Andy Blunden's ideas) and Iranian Marxist tradition (especially Kamal Khosravi's ideas). In other words, my voice is a (very compact) critical dialogue between one of the most logically developed theories of CHAT and Iranian Marxist tradition. If you like, it is a dialogue between East and West (or between a major voice within 'Middle Eastern Spirit' and rest of the world), a critical dialogue between cultures that have experienced colonialism, Imperialism, and finally Globalism in different ways. I am sure, most of us would not perceive this way of theoretical research as a novel one. During the years 1814-1819, Goethe was doing a practice, in which its result was a collection of poems that their concept has been created as a critical dialogue (1819) between West and East (specifically Persian Culture). I am using a specific interdisciplinary mode of investigation in which its starting point can be found in Goethe (Blunden, 2010). Goethe Wrote "West-Eastern Divan", I have no choice but to write "East-Western Divan! Let's start with the eastern tradition: Iranian Marxist Tradition.

\section{Iranian Marxist Tradition and Twin Crises}

Young generation of Iranian scholars are observing a gradual development of a Marxist tradition among left wing activists and academicians. New concepts, methods, and new ways of political organization are arising during the first and second decades of twentyfirst century. One can refer to works of Asef Bayat $(2009 ; 2017)$ who conceptualized the particular mode of social movement in Iran and other Middle Eastern countries which are essentially different from modern, western way of activism. Vahabi (2015) has made an interesting study on the political economy of predation which is a common phenomenon in a country like Iran. Cyrus Bina has done significant studies on the role of Islamic ideology in modern Iran $(1992 ; 2014)$ and, based on his investigation on Iran's national oil company and degeneration of US oil cartels, he invites us to have a fresh look on the post-imperialist and globalized world economy (2013). Beside these international figures of Iranian Marxist tradition, there are other scholars and activists that write in Farsi and they are mostly unknown for western, English-speaking scholars. Kamal Khosravi, a Marxist activist and independent scholar, is one of them. Among his main theoretical contributions are his ideas on 'twin crisis' (2017) and the critical-revolutionary method of dialectic, based on Marx's concept of 'mode of existence' (2020). Introducing all of the unique contributions of Iranian Marxist tradition to the community of progressive activists needs to be done in another article. Here, I only focus on these two contributions of Khosravi, which I believe are dealing with logically universal problems.

What do we mean by 'Crisis of historical perspective on human self-emancipation'? It is a global crisis. All of us are right now experiencing this crisis, including you, dear readers. So, in order to understand this crisis, I recommend you to search for these arguments, in your own subjective experience. In a very exceptional way, the arguments that I have abstracted from my subjective experience of 'Global Crisis', as a Critical Psychologist in 
Iran, are true about your subjective experience too. It does not matter if you are in Europe, South America, Africa, or any other continent. These arguments are true about all of our subjective experiences.

All of us are dealing with different crises in our everyday lives, but none of us have any integrated, universal, or global solution in order to put an end to this nightmare. What do I mean by nightmare? It is a form (or process? development?) of gradually intensifying contradictions within and between different civilizations, in addition to intensification of climate crisis which, every month, it is getting harder and harder to control the global situation. People still have not found a specific solution in order to solve the multiform contradictions between human beings themselves and also nature. The basic unit of analysis that can grasp the psychological essentialities of 2020 is crisis situation. As Vasilyuk (1988) has described a crisis situation, it is a specific critical situation that the subject has multiple, contradictory motivations, realization of which is impossible. For example, a worker needs to go to work in order get wage, and also needs not to go to work in order to stay safe and healthy during the pandemic. However, she has lost her job and cannot go to work and, at the same time, she cannot stay home, because she needs to find a job. On another level, different social projects (companies, states, families, school systems, constitutions, and etc.) are struggling to survive the pandemic and the economic crisis, while there is no ready solution for all of us to emancipate ourselves (another level: class projects are missing). In the early twenty-first century, we have essentially different subjective experiences compared with those who have lived in the early twentieth century. In the early twentieth century, people's worldview or Weltanschauung (Freud, 1932), if you like, had a clear vision of what is the problem with our globe and what is the essence of the emancipatory practice that we need to do in order to historically emancipate ourselves. People had a concept of "how to emancipate future". Many of these conceptual frameworks of "how to emancipate future" were based on Metaphysical/Religious axioms, and some of them were based on Ontological categories that have been developed in the history of 'Philosophy'. World Revolution of early twentieth century was the outcome of collaboration between all the projects and all the activists that tried to emancipate their future. By looking at history of different regions, one can find many examples of Socialist, Nationalist, Religious, and other forms of social revolutions, social movements, and social non-movements (Bayat, 2009; Hooshyari, 2020) in that stage of history. But right now, at 2020, the concept of "how to emancipate future", the worldview or Weltanschauung itself, is in crisis. Most of us have abandoned all worldviews that have the vision of emancipating human kind and have retreated to theories of emancipating individual identities: women, black, LGBT, refugee, disability, indigenous societies, trees, oceans, jungles, rivers, penguins, pandas, technologies, and so on. This retreat is a symptom of our crisis of historical perspective of human self-emancipation.

Let me show the crisis of historical perspective on human self-emancipation in some examples:

Some of us, active in social movements related to climate change crisis, have the experience of confusion about strategies and tactics of struggling for the Earth. For example, it appears that oil industries have no intention of listening to climate crisis activists, states, or any other authority. And no one has any feasible plan for shutting down oil production immediately. How can we solve this problem?

WHO, in late January, had called for global emergency (Kennedy, 2020) and importance of quick, global response. Global response includes shutting down inessential companies and economic activities, exercising global physical distancing, lockdown of effected regions, social solidarity, and so on. But WHO had absolutely NO feasible plan 
for realizing these objects and emancipating humans from this situation. Consequently, we faced global pandemic of COVID-19.

All of the local, national, and international projects, from a social psychological point of view, are experiencing the crisis of historical perspective on human self-emancipation. Distinctly, but interrelated to the previous crisis, one can speak about crisis of theory in emancipatory social science. What is this crisis? Not only we cannot create a unified and enlightening picture of our subject matter, i.e., humans' social life, but also we are unable to transform it. Our categories are failing to represent the true relation between social elements and factors of reality. Emancipatory social science in twenty-first century has retreated to methodological individualism: take the example of intersectionality (Dhamoon, 2011). It is presumed in this mode of investigation that each category that expresses a specific kind of oppression (like gender, race, class, etc.) has its own ontological origin in which its essential definitions should be extracted independent of other categories that express other oppressions. It seems that each oppression belongs to a different world and then these entities from different worlds are going to intersect to each other, just like some cars crashing in a crossroad! Unlike the metaphysical axioms of theory of intersectionality, we are living in a social life that all of these oppressions are internally related to each other in a single and unified totality. This is also true about apparently one of the most advanced concepts of social theories that attempts to understanding human's activities in everyday life. The Weberian (1905) concept of life conduct (Lebensführung), appropriated by German-Scandinavian Critical Psychology (Schraube \& Hojholt, 2015), is about understanding human's struggle to integrate contradictory but originally independent aspects of social life (e.g., economic activities, objectified in The Market, political activities, objectified in The State, ethical activities, objectified in Religious Institutions, and so on). This concept has been appropriated by Munich Sociological Group and then appropriated by Klaus Holzkamp and now is the central concept in the conceptual framework of German-Scandinavian Critical Psychology (Kritische Psychologie). Here also, one can see the problem of methodological individualism. It is true that process of everyday living consists of integrating contradictory aspects, but these aspects are all parts of a single, unified world of everyday life.

We are still failing to prepare the theory that enables us to make critique of social life. What we mean by critique is not only making enlightenment about our subject matter, but also transformation of it. In early twentieth century, people have the sufficient theoretical tools to make a critique of social life. Nineteenth century social science (like Marx, Engels and Hobson's political economic studies, Hegel's Logic, rich Russian literature, like Chernyshevsky, and so on) helped Vladimir Lenin and other revolutionaries in Russia to develop their understanding of the global crisis situation and to transform the global social situation. Without endorsing a Leninist point of view, or childishly calling for a new international based on the classic forms of political organizations, it is important to admit that twentieth century had created its own distinct forms of critique of social situation. However, right now, one can observe Tedros Adhanom director of WHO saying that "we only have limited power to give advice to governments. It is up to them whether to take them seriously or not" (Adhanom, 2020, April 29th). And more important than those political projects that have been retreated into real politics, current social revolutions, social movements, and social non-movements are unable to reach a global integrity in order to perform global Ethical Politics (Blunden, 2003) of twenty-first century. Or let us say twenty-first century's global revolution. Some of the readers may find the concept of global revolution an outdated, or even normatively dangerous concept. However, it is 
very hard to imagine a solution to global climate crisis or global economic crisis without a global revolution.

In conclusion, not only all the local, national, and international projects are psychologically experiencing crisis of historical perspective on human self-emancipation, but also, we lack proper and prepared theoretical tools to critique our subject matter, human social life.

\section{Modes of Existence of Capital and Mode of Collaboration of Capitalist Projects}

How can we explain global crisis situation? How is it possible to understand the crisis of historical perspective while our theory, itself, is in deep crisis? In what follows, I outline a draft of proposed conceptual framework which can possibly serve as a small step in resolution of the twin crisis.

Mode of existence has raised as an answer to the problem of rational unfolding (Entwickeln) of reality within a theory. How is possible to unfold different aspects and domains of reality without falling into methodological individualism? How can we build a psychological theory without losing the social world outside the consciousness? Khosravi (2020a) introduces a Marxian dialectical method which can help us in this endeavor. What we mean by mode of existence is

"the way, the space of presence, and existence of thing, event, relation, or reality as a whole; i.e. including all aspects that can be referred to root, basis, foundation, essence, and form of appearance, form of realization, presence, and also all their manifestation in -epistemologically true or false- interaction with consciousness." (Khosravi, 2020a:15)

It is clear in this definition that what we are going to investigate is reality as a whole. And the whole includes three modes of existence (a) essence, (b) form of appearance (of the essence), and (c) their interaction with consciousness. Our world-full psychology can rationally unfold reality by starting from interactions of appearances of reality with consciousness and then can rationally follow the path into another modes of existence of reality which are not essentially psychological. Although this critical dialectic provides us a method to unfold the whole of reality, it does not provide us sufficient concepts to understand the nature of consciousness and its specific mode of interaction with reality.

Tradition of CHAT is also following the Marxian path of investigation (Blunden, 2010; Sannino \& Engestrom, 2018; Vasilyuk, 1988; Dreier, 2020) and it has done important investigations on the psychological aspect of reality. Many CHAT scholars have argued that consciousness cannot be studied as an independent element. The basic unit of analysis that can grasp the essentialities of interaction between consciousness and reality is artifactmediated action. The smallest unit which is both a unit of consciousness and a unit of social behavior. This is the insight that creates the possibility of critical dialogue between CHAT and one of the important debates in Iranian Marxist tradition: the debate about method.

Vygotsky's molecular unit of artifact-mediated action would give us interesting insights about people's psychology. He also proposed a unit for analysis of social formations: 'concept', but 'concept' was understood as an aggregate of artifact-mediated actions. The next generation of cultural psychologists clarified this approach by using the unit of social life, 'activities' rather than 'concepts' which has the connotation of being 
something internal to consciousness. Different writers have used different terms for this macro-, or molar unit, of social life. Leontyev (2009) used 'activities' and Dreier (2020) used 'social practices' while Blunden (2014) used 'collaborative projects'. I take the liberty of appropriating Blunden's 'collaborative project' because unlike 'social practices' and 'activities', 'projects' has the connotation of changing social life, rather than simply reproducing social life.

Projects, as aggregate of goal-oriented actions that share a certain motive, are the units that appear to us in society. People collaborate with each other in order to realize the motive of the project. A project is not an aggregate of individuals contributing to it, but of the constituent actions. People can start to collaborate with a project, or cut their contribution. However, the project will continue its existence. For example, a company, understood as a project, that as a whole have the motive of profit making, would still exist if some of its workers get fired. On the one hand, the limiting case of a project is the one that is restricted to a body, a person, which, we can call it a life-project. A life project is also an aggregate of goal-oriented actions, in collaboration with others, that as a whole have a certain personal motive. Since, a life-project is an aggregate of actions, and each action is the molecular unit containing the nature of interaction of consciousness with reality, so the life-project can be seen as the molar or macro unit, illustrating the interaction of consciousness of a person with reality as a whole. On the other hand, multiple projects, collaborating with each other, are reproducing and transforming the essential characteristics of a society, its structures, if you like. What are the companies, banks, the state, police, schools, and families producing/ reproducing? What is the essence of these collaborative projects? Which social structures are being reproduced/transformed by collaboration of people in these projects? This is also a controversial question. However, if we continue our Marxian line of thought, consistent with the critical dialogue between CHAT and Iranian Marxist tradition, that essence is those historical conditions that have made abstract labor possible (Marx, 1976; Khosravi, 2019; Rubin, 2007). What are these conditions?

First: almost all the members of a society should be separated from the objective conditions of doing their work: their means of subsistence (food, shelter, cultural needs and so on) and also their means of production (working material, natural resources, space of work and so on). Second: all these working conditions should be handed over to certain institutions or persons, and people or projects can have access to these working conditions under certain circumstances imposed by those institutions. Third: The motive of handing over the working conditions to certain institutions is not for their consumption. They should use them in the process of production in order to accumulate more and more of these working conditions. Fourth: members of society who do not have the conditions for working and living on their own, are free to exchange their only property, (i.e. their labor-power) with means of subsistence and have access to objective conditions of production in order to produce commodities which do not belong to them.

The aggregate of those projects (companies, the state, police, banks, etc.) that, as a whole, have the motive of reproducing these conditions can be named as the capitalist class-project.

But each project that participates in the whole capitalist class-project has a particular role in the realization of conditions for abstract labor. Each project is doing its role by reproducing a given system of norms. For example, the police has significant role in realization of the first condition, the separation of members of society from objective conditions of work. The established juridical system reproduces the main laws that 
protect the institutions or people who have captured the objective working conditions. The education system participates in creation of free subjectivities that have the fundamental capacities to exchange within society. While the companies have the particular role of accumulating working conditions, hence, each capitalist class-project consists of many capitalist projects that their immediate motive is incomprehensible unless one grasps them within wider organisms: capitalist class projects. ${ }^{1}$

Each capitalist project is constituted by aggregate of actions performed by many subjects. Although each action serves a certain goal within the project, it also has a certain meaning for the subject. A meaning that cannot be understood unless one situates it in relation to meaning of other actions that constitutes the life of that specific subject, i.e., his/her lifeproject. One can assume that the motive of each capitalist life-project is to reproduce his/ her labor-power and, at the same time, increase the degree of his/her control over the objective working conditions, participating in different capitalist projects. For example, the constitutive actions of the life-project of a typical worker can be grasped by this.

In conclusion, a capitalist social life, as a whole, can be unfolded in three different modes of existence: (a) capitalist class-project, (b) capitalist projects, and (c) capitalist lifeprojects. One can see the relation between these three modes of existences in the table below:

Modes of existence of capital

\begin{tabular}{lll}
\hline $\begin{array}{l}\text { Form of semblance (Schein/ } \\
\text { Scheinformen) }\end{array}$ & $\begin{array}{l}\text { Form of appearance (Erschein- } \\
\text { ungsform) }\end{array}$ & $\begin{array}{l}\text { Essence/intrinsic nexus (innerer } \\
\text { Zusammenhang) }\end{array}$ \\
\hline Capitalist life-projects & Capitalist projects & Capitalist class-project \\
\hline
\end{tabular}

In our theoretical framework, we need to unfold the reality from life-projects, as the manifestation of interaction between consciousness and reality, into other modes of existence of reality, i.e., projects and class-projects.

In various Marxist traditions, it is often obvious that when we talk about reality, it has two dimensions: the essence and the appearance; the internal and external. Or the intrinsic nexus and external manifestation. But here, we are dealing with three dimensions (Khosravi, 2020b), which the third one is a form of resemblance (Schein/ Scheinformen). Before further elaboration of our psychological theory, we need to focus on this category and understand its significance.

\section{Semblance (Schein/Scheinformen) and Collaborative Reason}

In Hegel's Logic, the early moment in the process of activating 'the concept', the essence, appears in the form of semblance (Scheinformen). Form of semblance, as the earliest formation of a reality, is like a situation when one is staring into the mist to see what is causing the noise which sounds like an approaching vehicle and you get the first glimmer of it by understanding that it might be a car. Khosravi insists that 'form of semblance' has to

\footnotetext{
${ }^{1}$ It is worth noticing that in each social formation there exists many capitalist class-projects competing with each other. One can clearly investigate the traces of these competitions via the conflicts and contradictions in each capitalist project. The Parliamentary State is a good example to detect different capitalist class-projects.
} 
be considered as a distinct mode of existence of a reality which has specific characteristics which distinguishes it from more developed moments in the process of activating the concept.

Let us unfold this issue with the help of an example: consider a company as the basic unit of analysis of capitalist society (Blunden, 2010:218). Abstract labor, as the essence, or the main motive of capitalist class project appears in the form of certain cultural norms or ethics of collaboration in that given company. Let us suppose that these cultural norms are western, secular, and modern norms that enable people to exchange in order to make profit for the company. So, a company has a developing form (the cultural norms) and a content (the abstract labor). One can ask a very tricky question that how these forms interact with consciousness or subjectivity? These forms appear to consciousness in a distinct form. So, the content of this distinct form is a formic content (Formgehalt). This formic content is a form of appearance that, in its interaction with consciousness, has appeared in this distinct form: form of semblance. ${ }^{2}$

Cultural norms in that given company serve as scope of possibilities (Schraube \& Osterkamp, 2013; Dreier, 2020) for the workers. They can realize those possibilities by their own will. Although each worker, each life-project in our exemplary company is realizing certain norms within the scope of possibilities, the will of workers is not determined by scope of possibilities. It is not determined by the norms themselves that how workers collaborate with each other. The norm they realize by their activity is the matter of their personal reasons (Schraube \& Osterkamp, 2013; Dreier, 2020) or what I like to call collaborative reasons. Collaborative reason is the specific (and earliest) form of appearance of norms in the subjectivity of those workers, or, in other words, the specific (and the earliest) way that they conceive and work on the reality. In fact, the whole of cultural norms, or let's say the whole of scope of possibilities cannot be grasped by collaborative reason of one of the workers. One worker may think with herself that the only choice she has is to obey the rules of company. The other one may think that it is possible to negotiate the rules with the boss. Other workers may think that workers must have solidarity with each other and go on a strike in order to rule the company by their own will. All of these norms constitute the whole scope of possibilities within that company. However, in each collaborative reason, one can find out that these norms have found a specific form. Some of the norms are dominant or other norms are missing. In other words, for each worker, reality sembles itself in a unique form: a unique form of semblance. After these explanations about form of semblance and collaborative reasons, we can complete our table and then continue our investigation:

\begin{tabular}{lll}
\hline Modes of existence of capital & & \\
\hline $\begin{array}{l}\text { Form of semblance (Schein/ } \\
\text { Scheinformen) }\end{array}$ & $\begin{array}{l}\text { Form of appearance (Erschein- } \\
\text { ungsform) }\end{array}$ & $\begin{array}{l}\text { Essence/intrinsic nexus (innerer } \\
\text { Zusammenhang) }\end{array}$ \\
\hline $\begin{array}{ll}\text { Capitalist life-projects: } \\
\begin{array}{l}\text { Realize norms of capitalist } \\
\text { projects }\end{array}\end{array}$ & $\begin{array}{l}\text { Capitalist Projects: } \\
\text { Realize goals of capitalist class- } \\
\text { project }\end{array}$ & $\begin{array}{l}\text { Capitalist Class-project: } \\
\text { Follows 4 goals of creating abstract } \\
\text { labor }\end{array}$ \\
$\begin{array}{lll}\text { Content: (formic content) cultural } \\
\text { norms/ethics of collaboration }\end{array}$ & $\begin{array}{c}\text { Form: cultural norms/ethics of } \\
\text { collaboration }\end{array}$ & \\
& $\begin{array}{c}\text { Content: goals of capitalist class- } \\
\text { project }\end{array}$ & \\
\hline
\end{tabular}

\footnotetext{
2 Again, one has to be cautious that it is different from illusion, since it is the reality itself that pretends to be something else, by hiding its original content or its essence.
} 
Based on this method of rational unfolding of reality, our psychological theory should start by investigation of life-projects; their collaborative reasons which reveal a psychological conception of reality from the standpoint of a given subject. The motive(s) that guide the whole of the person's activities will constitute his/her life-project. By careful study of multiple life-projects that are realizing a certain cultural norms, one can study a project that is going on by these people. Of course, each of these people has its unique understanding of that project that will be expressed in his/her unique collaborative reason. By abstracting the cultural norms from these multiple collaborative reasons, one can grasp the form of appearance of a project which its content is a specific class-project.

Having this conceptual framework in mind, let us look at this paragraph from chapter 13, volume 1 of Das Kapital:

"Being independent of each other, the labourers are isolated persons, who enter into relations with the capitalist, but not with one another. This co-operation begins only with the labour-process, but they have then ceased to belong to themselves. On entering that process, they become incorporated with capital. As co-operators, as members of a working organism, they are but special modes of existence of capital. Hence, the productive power developed by the labourer when working in co-operation, is the productive power of capital."

Now, it is clear that Marx, by calling the workers as 'special modes of existence of capital', is inviting us to observe that the life-project of these workers, the collaboration between them is nothing but a way of presence of capital itself. These workers, as the productive power of capital, are realizing the goals of class-project of capital (abstract labor) which is another way of presence of capital. We cannot understand basic unit of capitalist social life (i.e., a company), unless we consider these three modes of existence of capital, as a whole.

In summary, in the world that its psychological essentialities can be grasped by 'crisis situation', while the twin crises of 'historical perspective on human self-emancipation' and 'emancipatory social theory' are the characteristics of our contemporary era, I hope that the critical dialogue between 'Iranian Marxist tradition' and CHAT would serve as a small step in resolution of global crisis situation.

\section{References}

Adhanom, T. (2020, April 29th). WHO declares its highest emergency alert on January 30. https://www. instagram.com/tv/B_kRc0QDiXo/?igshid=1ruwilfl4gzqw

Bayat, A. (2009). Life as Politics: How Ordinary People Change the Middle East. Stanford University Press

Bayat, A. (2017). Revolution Without Revolutionaries: Making sense of the Arab Spring, Stanford University Press

Bina, C. (1992). Modern capitalism and Islamic ideology in Iran. US: Palgrave.

Bina, C. (2014). A prelude to the foundation of political economy: Oil, war, and global polity. US: Palgrave.

Blunden, A. (2003). Ethical Politics and Alliance Politics. Online magazine of ethicalpolitics. https://www. ethicalpolitics.org/ablunden/works/arena_ethical_politics.htm

Blunden, A. (2010). An interdisciplinary theory of activity. Boston: Brill.

Blunden, A. (2014). Collaborative projects: An interdisciplinary study. Boston: Brill.

Dhamoon, R. K. (2011). Considerations on Mainstreaming Intersectionality. Political Research Quarterly, 64(1), 232.

Dreier, O. (2020). Critical Psychology: Subjects in Situated Social Practices, in Cultural Historical and Critical Psychology: Common Grounds, Divergences and Future Pathways, Fleer, M., \& Gonzales Ray, F. UK: Springer 
Freud, S. (1932). New Introductory Lectures on Psycho-analysis. Hogarth Press. Marxists Archive. https:// www.marxists.org/reference/subject/philosophy/works/at/freud.htm

Goethe, J.W.V. (1980 [1819]). West-Eastern Divan. London: MCMXIV. J.M. Dent \& Sons LTD. Internet Archive. https://archive.org/details/westeasterndivan00goetuoft/page/n11/mode/2up

Hooshyari, L. (2020). Role of Social non-movement in understanding 'Global Crisis Situation'. International Conference of Psychology of Global Crisis. Paris

Kennedy, M. (2020). WHO Declares Coronavirus Outbreak A Global Health Emergency. Online Magazine of NPR. https://www.npr.org/sections/goatsandsoda/2020/01/30/798894428/who-declares-coronavirusoutbreak-a-global-health-emergency

Khosravi, K. (2017). Crisis of theory and crisis of historical perspective. Online Magazine of Critique of Political Economy. https://pecritique.com/2017/05/30/\%D8\%A8\%D8\%AD\%D8\%B1\%D8\%A7\%D9\% 86\%D9\%90-\%D8\%AA\%D8\%A6\%D9\%88\%D8\%B1\%DB\%8C-\%D9\%88-\%D8\%A8\%D8\%AD\%D8\% B1\%D8\%A7\%D9\%86\%D9\%90-\%DA\%86\%D8\%B4\%D9\%85\%E2\%80\%8C\%D8\%A7\%D9\%86\%D8\% AF\%D8\%A7\%D8\%B2-\%D8\%AA\%D8\%A7\%D8\%B1\%DB\%8C/

Khosravi, K. (2019). Abstract Labor and Socialism. Online Magazine of the Critique. https://naghd. com/2019/04/18/\%DA\%A9\%D8\%A7\%D8\%B 1-\%D9\%85\%D8\%AC\%D8\%B 1\%D8\%AF-

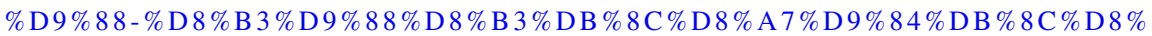
B3\%D9\%85/

Khosravi, K. (2020a). New step in Marxian critique. Online Magazine of Critique. https://naghd. com/2020/04/26/\%da\%af\%d8\%a $7 \%$ d $9 \% 85 \%$ db $\% 8 c-\%$ d $8 \%$ aa $\%$ d $8 \%$ a $7 \%$ d $8 \%$ b $2 \%$ d $9 \% 87-$

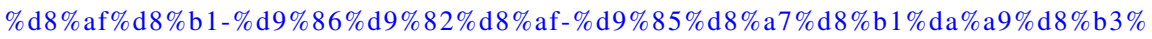
$\mathrm{db} \% 8 \mathrm{c} /$

Khosravi, K. (2020b). Essence, appearance, pretence. Online Magazine of Critique. https://naghd.com/ 2020/06/08/\%d8\%b0\%d8\%a7\%d8\%aa\%d8\%8c\%d9\%be\%d8\%af\%db\%8c\%d8\%af\%d8\%a7\%d8\%b1\% $\mathrm{d} 8 \% 8 \mathrm{c} \% \mathrm{~d} 9 \% 81 \% \mathrm{~d} 8 \% \mathrm{~b} 1 \% \mathrm{~d} 8 \% \mathrm{a} 7 \% \mathrm{~d} 9 \% 86 \% \mathrm{~d} 9 \% 85 \% \mathrm{~d} 9 \% 88 \% \mathrm{~d} 8 \% \mathrm{af} /$

Leontyev, A. (2009). Activity and Consciousness in The Development of Mind Erythrś Press Levine R A \& White M I 1986 Human conditions: The cultural basis of educational development. Routledge London

Marx, K. (1976). Capital: A critique of political economy. Moscow: Progress Publisher.

Rubin, I. I. (2007 [1923]). Essays on Marx's Theory of Value. India: Harper Collins

Sannino, A., \& Engeström, Y. (2018). Cultural-historical activity theory: founding insights and new challenges. Kul'turno-istoricheskaya psikhologiya = Cultural-historicalpsychology, 14(3), 43-56. (In Russ., abstr. in Engl.). https://doi.org/10.17759/chp.2018140304

Schraube, E., \& Osterkamp, U. (2013). Psychology from the standpoint of subject: selected writings of Klaus Holzkamp. USA: Pelgrave.

Schraube, E., \& Hojholt, C. (2015). Psychology of Conduct of Everyday Life. Routledge

Vahabi, M. (2015). The Political Economy of Predation: Manhunting and Economics of Escape, Cambridge University

Vasilyuk, F. (1988). The Psychology of Experiencing. Harvester Press

Weber, M. (2002 [1905]). The Protestant Ethics and The Spirit of Capitalism: and Other Writings. Penguin

Publisher's Note Springer Nature remains neutral with regard to jurisdictional claims in published maps and institutional affiliations. 